\title{
Digital humanities and development of the biographical method*
}

\section{L.E.Artamoshkina ${ }^{1}$, K. Morawski², D. E.Prokudin ${ }^{1}$}

${ }^{1}$ St. Petersburg State University,

7-9, Universitetskaya nab., St. Petersburg, 199034, Russian Federation

${ }^{2}$ Karkonosze State University of Applied Sciences,

18, Lwówecka, Jelenia Góra, 58-503, Poland

For citation: Artamoshkina L.E., Morawski K., Prokudin D. E. Digital humanities and development of the biographical method. Vestnik of Saint Petersburg University. Philosophy and Conflict Studies, 2021, vol. 37, issue 2, pp. 310-321. https://doi.org/10.21638/spbu17.2021.210

The article deals with the methodological foundations of the biographical method in the context of digital humanities. The bidirectional character of biography leads us to the problem's methodological level: social predicament of the individual world and reciprocal determinability of the social world by the individual world. The biographical method is closely linked to thematization of subjectivity. The biographical method's methodological problems are connected with context, reference, authenticity, and reflexivity. The authors link the biographical method with memory studies and emphasize that the turn to memory is associated with many theoretical questions and controversies related to the status of history as a science and its relation to the field of human memory. The multidirectional biography studies reveal the lack of a conceptual apparatus, common for the interdisciplinary space of humanities, which allows to develop the criteria for comparability of scientific research results. The authors associate the further development of the biographical method with the development of the modern information society. They note the prospects of using the methods of digital humanities associated with the search, selection and analysis of texts presented in digital form. The rationale for this thesis is that at present there is a constant increase of electronic texts that can be used both for the development of the biographical method and serve as its empirical base. The article demonstrates the possibility of applying the biographical method using the tools of digital humanities on the examples of research on the history of science, which are part of the world's cultural heritage.

Keywords: biography, biographical method, F. Znaneckij, cultural memory, digital humanities.

\section{Biography and biographical method}

From its origins, the genre of biography was very broad, embracing the texts of curriculum vitae, heroic deeds of historical personalities, hagiographies; it supported history and later became the subject of literary studies. Other scientific studies paid either occasional, or as in psychoanalysis, specific attention to the genre of biography. The concept of biography has meanwhile one more meaning: it is the conception of re-

* The article was prepared with the support of a grant from the Russian Foundation for Basic Research no. 19-011-00775 "The topology of cultural memory in dialogue of generations".

(C) St. Petersburg State University, 2021 
ality inherent in human life regardless of having it reflected in written cultural sources. Concerning this, the concept has the same ambivalence, as, for example, the concept of history, meaning both a process of real events, deeds and fulfillments, and its very reproduction in historical writings and other types of texts. This ambivalence of meaning should be particularly considered since the biography was attracting the attention of cultural researchers, theorists, and historians of culture. Such attention is stipulated, first of all, by the desire to study culture without digressing from its bearer/creator, but through him and with him. In this sense, the biography appears as an actual realization of cultural potential and as the determination of its values, standards, institutions, as the structuring of human life of the given era and the foundation of human mutual identification; it is the source for the feeling of belonging to a certain cultural situation. On this intersection of the single and the universal, a human being begets self-understanding and the meaning of their actions. Thus, culture presents itself through the biography to history and to the present. Therefore, by studying biography, a man's life, we actually study by what and how the culture is represented in it. The biography is the living and particular language of culture.

The biography also acquires the status of written evidence of human life. It exists as a text in two main forms: the autobiography and the biography. The autobiography is the way to self-representation, while the biography is the way to present the other, the "hero" of the story, rather than the biography's author.

Depending on the origin of biographical text (memoirs, diaries, autobiographies, etc.), a researcher could be interested in its other features and attributes: to what extent the author was able to recreate himself with all available means in the sociocultural context and to realize the ratio of universal-cultural and individual-personal in his life. The "author's biography" allows its researcher to ask questions: how does the biography lead to an understanding of culture and the human being, how adequate is it, and what conditions and premises determine evaluation, elucidation and interpretation of a biographical text?

The current study opens a new problem field for theory, cultural history and cultural studies. Biography research in many other humanities has a tendency, in its institutional design, to separate into other disciplines, such as cultural and historical personology and biographics. This encourages us to understand the necessity of a certain methodological basis, the conceptual analytical foundation of the biographical text in cultural and historical discourse. Multidirectional biography studies reveal the lack of a conceptual apparatus that is common for the interdisciplinary space of humanities, which allows to develop the criteria for comparability of scientific research results.

The relevance of the current research is determined also by intense changes related to the appearance of such new forms of biographical text in culture as the virtual journal/ diary, the "live journal". The establishment of a conceptual apparatus and the study of possible principles of biographic text's usage for the analysis of modern culture makes this study important.

Research into conceptual foundations of biographical texts suggests the examination of a correlation between sociocultural, narrative principles of its formation and realization in cultural and historical discourse. The basic premise is in the search for principles of correlation and mutual conditionality of several sources in culture: the social and the individual, history and the present. 


\section{Roots and background}

The biographical method owes its roots to Goethe (Poetry and the Truth, the personality in a novel), Herder (life description as a path to the "true life study of the soul"), ethnography (description of outstanding personalities among primitive peoples), psychology, and psychoanalysis. It is clear that the biographical method originates from the "philosophy of life" and, first of all, from the German tradition. Later, in the 1920s, the biographical method was actively used by F.Znaniecki [1] in his sociological studies. As he was examining a rural community and the life of immigrants, he considered biographical data as well as social and psychological material (V. Tomas, F.Znaniecki). Analysis of "the world of certain people's viewpoints" was taken into consideration. Subsequently, the biographical method was contrasted with the statistical method, which is believed to be more scientific. The Vienna researchers (Charlotte Büler) used the biographical method in psychology and teaching [2]. Researchers usually complain about difficulty in interpretation and the use of the materials obtained with the help of the biographical method. They would often say, "We are sitting on a pile of materials and yet cannot find the key message that would help us interpret it".

By mid- $20^{\text {th }}$ century, the process of institutionalization of directions associated with the use of the biographical method had begun. Alan Nevins set up the Oral Research Center at Columbia University in 1948. Then, the Association for Oral History Research was established in 1960s. The biographical method tended to be used in the area denoted as oral history in the English language tradition. Biography is seen here as oral history reflected in interviews and memories. Just like in sociology, the most reliable factors for assessment of biographical material are authenticity and reliability.

A project for research into autobiographies was launched in Europe in the late 1970s - early 1980s. France was the most active party in this research. For example, Lejeune's works were published and a conference was held that triggered research of the same kind in Russia. Scientists have been advancing their research of similar issues in Russian literary studies and literary history. A new area of research, biography studies, has been formed within the disciplinary space of Russian historical science. However, the suggested definition of the subject for biography studies reveals the discipline's dependence on sociology with its tendency for quantitative evaluation. Furthermore, biography studies as a summary of individual biographies becomes a source for empirical data for the humanities. We define biography as a life description, and we provide grounds for it being a biographical method in history and sociology as sciences. We are leaving aside the obvious meaning of biography that links it to the text, which was the key notion of the $20^{\text {th }}$ century science when the biographical method came into existence. The descriptive principle contradicts the systematic principle - "the necessity for a system of biographies".

It is very important to mention the concept of social action by Florian Znaniecki, the famous Polish scientist, who paved a new way for $20^{\text {th }}$ century sociology and provided a meaning of the biographical method in his theory, which is vital for the onset of our research. Not all modern sociology studies can exist in the vast methodological space covered by Znaniecki, which narrows the biographical method down to biographical material that is necessary for a sociologist's empirical research [3]. 


\section{Biographical method: Relevance for research}

Let us place an emphasis on the part of the concept that is vital for us because it places the biography issue on a methodological level. In accordance with the concept of social action, Znaniecki introduces the notion of situation and insists on the definition of situations given by participating subjects, and on a thorough analysis of a biography as a way to understand a subject's influence and their role in social action [3]. This implies the bidirectional character of biography that leads us to the problem's methodological level: social predicament of the individual world and reciprocal determinability of the social world by the individual world. This is the "humanistic coefficient" that Znaniecki supported [1].

The meaningful level of biography established by Znaniecki establishes the background that we need in order to start searching for the categorial grounds that will allow the biographical method to serve as an "operator" for transition between different levels of research [4].

Participants of conferences devoted to the biographical method traditionally look into its methodology. However, they seldom go beyond attempts to find certain key methodological notions that could serve as a foundation for the biographical method. The following question arises: what notions are traditionally used?

We will name just a few recurrent ones: credibility, worldview, everyday life, life history, generation, collective memory, cultural memory, identity, text/context, authenticity, reference, and reflexivity. We believe that these are fairly common for both Russian and Western European scientific traditions.

The history of biographical forms of reflection, of different biographical text types, in European culture correlates with the history of the culture's formation. During our research, we examined and analyzed multiple sources representing different forms and genres of biographical text in Europe: curriculum vitae, confession, diary, genealogy, memoirs, (auto) biographical novel, and epistolary legacy.

One of the first and most thorough studies in the domestic tradition of biographical genres of antiquity was conducted by Sergey Averintsev in his Plutarch and Antique Biography [5].

The biographical method is closely linked to thematization of subjectivity. As a result, it is frequently used in the humanities: sociology, history, art history, and psychology.

For example, sociologists refer to certain biographies in order to identify the social predicament of certain life journeys; biographies help to reconstruct the social experience, subcultural stylistic forms, and collective historical consciousness. The biographical method also helps to locate the origins of cultural samples and processes of socialization. It is employed in order to back up theoretical concepts in developmental psychology (Charlotte Bühler) and in personality theory [2]. In sociology, the biographical method legitimizes such concepts as "life pattern / life construction". Also, the method can be used in social sciences in order to research behavior from the point of view of institutional regulations.

The biographical method embraces approaches to the measurement and assessment of life and historical evidence, or data narrated to the researcher from the point of view of those who have lived these lives.

The oral history biographical method helps to determine credibility of the events discussed during interviews because it takes into account the historical and cultural value 
of the event, as well as the way the events are interpreted in a certain context. Credibility is defined as consistency in description of the same event by the same person in various interviews; it is also defined as coherence between the speaker's interpretation of the event and the event itself as presented in other (primary) sources (documents, photographs, diaries, letters).

A recent upsurge in popularity of the biographical method is caused by research into post-socialist societies. The biographical method's methodological problems are connected with context, reference, authenticity, and reflexivity. These problems become substantially obvious when biography is compared with autobiography, because the latter, unlike the former, is a narrative about practices, aimed at ontological reality and the truth; the truth here is considered from the author's unique point of view, with the author being both the narrator and the individual who sees himself/ herself as the author.

An autobiography's authenticity is the author's attempt to present his / her life in the most realistic way; it includes levels of representation and denomination. In their autobiographies, authors narrate not the stories of their personal ego, but personal life experiences that belong solely to them.

An autobiography is highly referential: 'I am talking about the events that happened to me. Both autobiography and biography are reflexive to a very high degree; they are expressed through a multilevel narrative.

It is essential to consider the possibilities and features of a personality's impact on culture, the extent to which a certain personality, in the integrity of its self-realization, influences culture-creative processes by the individual's behavior.

The above mentioned is the foundation for applying a biographic text in its methodological foundation as a tool for comprehensive analysis of forms and phenomena of social, economic, and political life; it defines broad possibilities for developing the strategy for such forms. The offered principles of analysis in the broad disciplinary field help with the implementation of practical interdisciplinary studies.

The group of concepts brought into research (biographic type, biographic writing, topology of image) serves as a basis for specification procedure development in a biographical text. The concepts help with the precise definition and determination of limits by using the biographic method - the very possibility of such a method. The biographical method can be used in the analysis of cultural and historical discourse actualized by the present.

\section{Time (for) memory}

The "time of memory" announced by Pierre Nora certainly questioned the dominant position of history as a vision or representation of the past. The successive increase of memory theories and practices related to it makes it possible to even speak about the "memory industry" [6, p. 127], including museum trade, political antagonisms related to (repressed, silent) memory, the market of books and scientific articles that recall memory as a key concept, as well as diary literature. We can use the more capacious concept of the so-called "ego-documents", which include biographies, memories, diaries, autobiographies, letters, as well as statements in official records, and records of legal, economic or political processes. The turn to memory, of course, is associated with many theoretical questions and controversies related to the status of history as a science and its relation to the field of human memory. In 1988, the work History and Memory by Jacques Le Goff 
was published [7]. The French historian defends history as a science that illuminates and cleanses human memory of errors. Even if we admit that history developed in collective memory, it cannot be synonymous with it, just like chemistry cannot be identical with alchemy or astronomy with astrology, according Le Goff. Historians, under the pressure of debates initiated by the postmodern trend, will defend history as a science proclaiming the need to redefine the concept of science itself, or perceive the historian as a translator in intercultural dialogue, pay attention to the subjective determinants of the historian's work and criticize the idea of linear time and historical progress [8].

Certainly, the past, regardless of whether it is included in scientific discourse or iridescent in the domain of individual and collective memory, turned out to be a constructed past (and this construction takes place within the dominant discourse of one or other social groups and identities) As P. Burke noted:

traditional account of the relation between memory and written history, in which memory reflects what actually happened and history reflects memory, now seems much too simple. Both history and memory have come to appear increasingly problematic. Remembering the past and writing about it no longer seem the innocent activities they were once taken to be. Neither memories nor histories seem objective any longer. In both cases historians are learning to take account of conscious or unconscious selection, interpretation and distortion. In both cases they are coming to see the process of selection, interpretation and distortion as conditioned, or at least influenced, by social groups. It is not the work of individuals alone [9, p. 43-44].

Therefore, the researcher will advocate a social history of memory, which at the same time prompts a strictly political question: who wants to induce one to remember something and for what reasons? Whose version of the past is preserved and stored (in science and memory)?

The development of various $20^{\text {th }}$ century discourses on memory can be linked to the coincidence of three factors [10, p. 15-18]. The first is associated with historical transformations. The Holocaust and World War II put the trauma category at the center as a response to extreme experience and "traumatic memory" (in this case, psychoanalytical tools are also used to conceptualize memory). Moreover, death marking the end of the spoken story of witnesses (i. e., the end of communicative memory) means relying on specific media or memory media (historiography, monuments, films, anniversary celebrations). It is a "cultural memory" (according to the formulation of A. and J. Assmann). The collapse of the Soviet Union marked the end of "cold war" history and binary memory. On the other hand, a multitude of national and ethnic memories came to the fore. Democratic transformations (e.g., in Central and Eastern Europe, South Africa) have led to questions about reconciliation and memory associated with it. The work of remembrance was also started by decolonization processes: granting voice to "peoples without History" is recognition of their version of the past (in addition to postcolonial discourses, memory functions in gender studies). Eventually, the events of September $11^{\text {th }}$ generated even more questions about the sites of memory.

The second factor is the change in media technologies and the role of popular media. The Internet has become a global archive, interactive and open. A. Erll recognizes the danger of "cultural amnesia", which concerns our memory functioning as "dead knowledge" on digital media. Certainly, this type of phenomenon raises the question of what is worth remembering. Memory also functions in mass culture (e. g., historical films, books, com- 
ics). Here, in its extreme form, it becomes pure fiction (e. g., a fictitious autobiography of B. Wilkomirski, who allegedly survived the extermination camp).

The last factor is the processes taking place within the scientific world (this concerns the humanities). The postmodern paradigm and its disbelief in great narratives come to the fore here. As Ewa Domańska writes, "while history was defined as an instrument of pressure and identified with modernism, the state, imperialism, scientism and anthropocentrism, memory was treated as healing medicine and an organ of redemption, referring to postmodernism and the "liberation" of groups whose history took the voice" [8, p. 14]. Postmodernism was activated in the form of a narrative turn that questioned not only contact with the past as part of historical discourse, but also the very status of history as a science. It becomes more literature, or - as one of the leading representatives of this trend Hayden White put it - a place of fantasy.

\section{Memories, media, biographies}

"The experiences of World War II influenced the existence of many generations. For Polish culture, the extent and depth of its effects became apparent after many years. Many literary and artistic works, plays, films, series, memories and scientific works were created. This spectrum also includes press publications that are the beginnings of camp literature", reads the introduction to the book by P. Gren Pamięć a media. Obchody wyzwolenia KL Auschwitz-Birkenau w dyskursie prasowym [11].

The author, analyzing about 300 press texts from 1945-2000, shows how the image of Auschwitz was shaped and discursively created. Auschwitz, as a "place of remembrance" and a symbolic synecdoche of evil as such, was entangled (and still is) in various ideological contexts that constructed a field of memory (official and unofficial, individual and collective).

"The memory of the camp $<\ldots>$ did not live its life and did not exist in a social vacuum. It was, in fact, susceptible to the influence of the environment and reflected current political trends, cultural patterns and the state of historical knowledge at a given moment" - notes Greń.

"Private and living memory" (generally, this is the memory of the Jewish and Polish people) was increasingly included in international martyrology as part of official state discourse, and in this form - e.g., in the Stalinist period - it served to identify the enemy (i. e., the Federal Republic of Germany, the western world). The anniversary of the liberation of the Auschwitz camp also served as anti-war demonstrations. After 1989, the media discourses about Auschwitz are more factual - they are often like memories without ideological (patriotic and nationalist) or religious pathos. It is rather, maybe uncomfortable or improper from the ideological and moral point of view, body memory. "Without pathos: not for the homeland, not for honor, but simply for the exhausted body, for ulcers, for typhus, for swollen legs $\langle\ldots\rangle$. We did not fight in the camp for the concept of a homeland or for internal reconstruction of a man. We fought for a bowl of soup, for a place to sleep, for women, for gold and watches from transports" [12, p. 6-8]. The change after 1989 also entails a change in the image of the Red Army as a liberation army and, no less important, the image of the local Polish population. Nevertheless, Polish-Jewish tensions were still extinguished. The $50^{\text {th }}$ anniversary of the liberation of the camp generated antagonisms in the field of memory, religion and national issues. For example, Szewach 
Weiss, chairman of the Israeli Parliament, intervened in "Polityka" regarding the ignoring by the then President of Poland Lech Wałęsa of the memory of a million Jews murdered in extermination camps.

The memory of the extermination, apart from the media world, also functioned in unpublished descriptions. In the camps, according to B. Shallcross, various materials became the memory medium: cell walls, wrapping paper, old bills, margins of other prints all things that were suitable for writing on [13]. Another way to save descriptions was to memorize them. To reach these last sources, and thanks to them also understand the individual biographies of Holocaust survivors, one should, first of all, use the biographical method. An extensive interview about life before the camp, in the camp and after, reveals camp experiences that have never been said before. These are memories of extermination, as well as narratives about the meaning of life in general [11, p. 80-85].

\section{Digital humanities in biography studies}

The development of the biographic method, first of all, needs to be connected with the development of the modern information society. Trends of informatization led to the penetration of technologies of an information society in different human practices. Also, information and communication technology have a direct impact on the development of humanitarian knowledge and the sciences connected with its establishment and the scientific directions. First of all, under the influence of informatization, there was such cross-disciplinary scientific direction as "Digital Humanities". Within this direction, different methods and approaches to carrying out scientific research in the humanities based on the use of information and communication technology begin to be applied [14-18]. These lead to the main areas of development of digital humanities:

- textual research (generally — linguistic);

- factual research of electronic collections;

- research of multimedia objects (including virtual reconstruction);

- research on the influence of a digital medium on the humanities in general [19].

In an information society, it is possible to observer the continuous increase of humanitarian knowledge represented in electronic (digital) form. First of all, it belongs to the humanitarian knowledge presented by the text. Respectively, effective use of this knowledge is impossible without the corresponding access mechanisms to it and the search for necessary information. This leads to the need to use texts for scientific research and the establishment of different information resources and information systems:

- electronic directories of libraries;

- full-text databases of scientific information;

- electronic open access archives (repositories) — institutional and thematic;

- online journals;

- thematic digital collections;

- historical digital archives;

- archives of white papers.

Furthermore, the modern person generates different texts that can be encountered in diverse information systems (for example, social networks, personal websites). 
Electronic texts that are currently compiled make it possible to use them for the development of the biographic method and creation of its empirical base. At the same time, instruments of access and information search in information systems allow for the selection and systematization of texts according to research purposes. Moreover, the different software functions for the implementation of context search and text analysis provides a powerful analytical base to the biographic method.

On the Internet today there are a significant number of websites submitting biographies of different scientists, artists, educators, businessmen, and politicians. From the foreign websites, the most well-known is Marquis Who's Who (https://www.marquiswhoswho.com). The database contains a vast number of biographies and access is provided on a commercial basis.

On the resource website "Encyclopedia of people and ideas" (http://www.abc-people. $\mathrm{com} /$ ) in the section "Catalogue of information and educational resources", links to noncommercial networks of biographical resources are posted (http://www.abc-people.com/ catalog.htm 02). The analysis of the resources presented in the directory demonstrates a wide variety of biographic information: biographical information about writers, composers, artists, historic figures, scientists, Heroes of the Soviet Union, etc.

The U.S. National Archives (https://www.archives.gov/research/alic/reference/biography-resources.html) posts data on different biographic resources on the Internet which represent searchable databases and dictionaries, and obituaries in the section "Biography".

On the website of Rutgers Library (Rutgers, The State University of New Jersey) the section "Biography" contains an annotated list with links to a wide assortment of biographical resources in all disciplines (https://libguides.rutgers.edu/biography).

The biographic section on the website of the library of Simon Fraser University (Canada) also contains a list of biographic editions available in electronic form via the library's website (https://www.lib.sfu.ca/find/other-materials/reference-sources/biographical-sources).

Domestic libraries are also included in activities for the systematization and submission of biographic information in electronic form. For example, the National Library of Russia created and supported "The guide to biographic electronic resources to national history" (http://nlr.ru/res/inv/guide44/, originator Yu. A. Kuzmin). It contains resources exclusively in Russian and includes databases, lists of biographies for people connected to the past of Russia irrespective of their role and importance. Also, the guide includes memorial websites. Now the guide contains more than 500 references. Resources are located by the systematic principle based on traditional bibliographic indexes. There is a brief annotation for each record.

The Russian Academy of Natural sciences (www.rae.ru) has developed its own project of the network encyclopedia "Scientists of Russia" (http://www.famous-scientists.ru). This resource contains biographies of 4500 famous Russian scientists and specialists. Hyperlinks to their main publications are provided. The search mechanism makes it possible to search and sort biographies according to sciences, regions, and the number of times viewed and cited. The placement of biographies can be conducted independently after completing the corresponding registration (http://www.famous-scientists.ru/login/registration/). Uploading biographies and access to the database are free [20].

The possibility of applying the biographic method while using tools of the digital humanities can be shown on the example of research on the sociology of science and 
research on the history of science, which are connected with studying the scientific heritage of prominent scientists. It should be noted that this is a part of world cultural heritage.

On the website of the Center of Social Forecasting and Marketing (http://www.socioprognoz.ru), the historical and biographic project "Biographic Interviews with Colleagues Sociologists" (http://www.socioprognoz.ru/publ.html?id=385) created by the famous domestic sociologist B.Z. Doktorov is presented. The project represents online the book in which interviews were taken by Doktorov from domestic sociologists since 2004 [21-24]. This feature with the representation of such information makes it possible to replenish the database with new interviews and other materials. In addition, the representation of materials electronically allows searching for an interview not only in alphabetical order, but also by careers, education, place of work, and areas of research. The use of this resource enables conducting different research in the field of the history of science, for example, to study the generational dynamics of methodological preferences of domestic sociologists.

Another information resource that is of value for researches on the history of science is the American-Russian project known as the International Biography Initiative (IBI). It is devoted to the history of Russian sociology from the post-Khrushchev period and methodology of biographic research (http://cdclv.unlv.edu/programs/bios.html). This resource contains more than one hundred interviews, memoirs and autobiographical notes from famous Russian sociologists and a compilation of articles and materials of documentary character.

For the efficient analysis of a large amount of texts, there are various instruments, which are either software or web-based program platforms and tools. These tools make it possible to explicate contexts, as well as solve problems in regard to the comparative analysis of texts, identify relationships between words, etc. It enables the effective selection and systematization of texts when using the biographic method. An example of such an information system, created in Russia is the T-Libra system. It is designed to create multifunctional electronic full-text libraries accessible from the Internet and Intranet (http://www. softconst.ru/tlibra/). In addition to storing texts and their bibliographic descriptions, this information system contains full-text search tools:

- paragraph-oriented search is intended for an explanation of various terminological structures within a paragraph (cluster of paragraphs);

- frequency-based search is designed to clarify various "vertical" contexts (macrotexts) implicitly present in a single document or a full-text database in general.

These search options can be used for the analysis of texts, preliminary explication of their topics, selection of basic concepts, etc. The thematic selection of paragraphs in a single file allows one to obtain contexts relevant to research tasks [25].

One of the main problems of using the biographical method based on the use of digital humanities' tools is the availability of digital information resources and software tools. It should be noted that in addition to open resources and freely distributed software (free and open-source software), there are quite a large number of commercial resources (publishing platforms, abstract databases of scientific publications, electronic libraries) and commercial software. Therefore, not all researchers can equally use the biographical method in their research through approaches and methods in the digital humanities. For 
this purpose, we founded a centre for memory studies two years ago - Biography Research Centre "AITIA" and its corresponding website (BRC, http://biographycentre.org).

\section{References}

1. Znaniecki, F. (1968), The Method of Sociology, New York: Octagon Press.

2. Bühler, C. (1972), Selbstdarstellung, in Pongratz, L. J., Traxel, W. and Wehner, E. G. (eds), Psychologie in Selbstdarstellungen, Bern: Huber, pp. 9-42.

3. Znaniecki, F. (1965), Social Relations and Social Roles, San Francisco: Chandler Pub.

4. Znaniecki, F. (1967), Social Action, New York: Russell \& Russell.

5. Averintsev, S. (2004), Plutarch and Antique Biography, in Averintsev, S., Obraz antichnosti, St. Petersburg: Azbuka-klassika Publ., pp. 225-465. (In Russian)

6. Klein, K. L. (2000), On the Emergence of Memory in Historical Discourse, Representations, no. 69, special issue: Grounds for Remembering.

7. Goff, J.Le (1992), History and Memory, transl. by Rendall, S. and Claman, E., New York: Columbia University Press.

8. Domańska, E. (ed.) (2002), Pamięć, etyka, historia, Poznań: Wydawnictwo Poznańskie.

9. Burke, P. (1997), Varieties of Cultural History, New York: Ithaca, Cornell University Press.

10. Erll, A. (2018), Kultura pamięci. Wprowadzenie, transl. by Tepek, A., Warszawa: Wydawnictwo Uniwersytetu Warszawskiego.

11. Greń, P. (2017), Pamięć a media. Obchody wyzwolenia KL Auschwitz-Birkenau w dyskursie prasowym, Kraków: Aureus.

12. Nel-Siedlecki, J., Olszewski K. and Borowski T. (1998), Byliśmy w Oświęcimiu, Warszawa: Wydawnictwo Uniwersytetu Warszawskiego.

13. Shallcross, B. (2010), Rzeczy i zagłada, Kraków: Universitas.

14. Borisov, N.V., Nikitin, A.V., Smolin, A.A., Trushin, V.A., Chepurov, A.A. and Chepurova, O.A. (2016), Multimedia Reconstruction of a Stage Event. "The Seagull" on Alexandrinsky Stage, First Night, 17 October 1896, International Culture \& Technology Studies, vol. 1, no. 1, pp. 15-23. Available at: http://cat. ifmo.ru/ru/2016/v1-i1/65 (accessed: 20.12.2019).

15. Borisov, N. V., Volkov, O. G., Nikitina, L. L., Nikolaev, A. O., Smolin, A. A. and Stolyarov, D. A. (2016), Application of Video 360deg Technology for the Presentation of the Solovetsky Monastery Cultural Heritage, International Culture \& Technology Studies, vol. 1, no. 1, pp. 24-31. Available at: http://cat.ifmo.ru/ en/2016/v1-i1/88 (accessed: 20.12.2019).

16. Borodkin, L.I. (2014), Virtual Reconstruction of Moscow Monasteries: Projects in the Context of Digital Humanities, Vestnik Permskogo universiteta, seriia Istoriia, vol. 3, no. 26, pp. 107-112. (In Russian)

17. Borodkin, L. I. (2015), Digital Humanities and Virtual Reconstructions in the Museum Space, in Role of Museums in Information Support of Historical Science, Moscow: Eterna, pp. 386-395. In Russian)

18. Kukovyakin, A. V. and Lyapin, S. H. (2017), Lomonosov's Universum: The Experience for Functional Integration of Virtual Atlas and Full-Text Library, International Culture \& Technology Studies, vol. 2, no. 1, pp. 6-12. Available at: http://cat.ifmo.ru/ru/2017/v2-i1/98 (accessed: 20.12.2019). (In Russian)

19. Thaller, M. (2012), Controversies around the Digital Humanities, Historical Information Science, no. 1, pp. 5-13. Available at: http://kleio.asu.ru/2012/1/hcsj-12012_5-13.pdf (accessed: 20.12.2019). (In Russian)

20. Stukova, N. Yu., Scientific biographic resources of the internet, Scientists of Russia. Available at: https://russian-scientists.ru/club/user/5/blog/6/ (accessed: 20.12.2019). (In Russian)

21. Doktorov, B.Z. (2014-2017), Biographical interviews with fellow sociologists. 4th ed., Moscow: TSSPIM. Available at: http://www.socioprognoz.ru/publ.html?id=385 (accessed: 20.12.2019). (In Russian)

22. Alekseev, A. N. (2015), Historical, and biographic search and Boris Doktorov's opening, Telescope: log of sociological and market researches, no. 1, pp. 48-50. (In Russian)

23. Doktorov, B.Z. (2007), Biographies for history, Telescope: log of sociological and market researches, no. 1, pp. 10-22. (In Russian)

24. Doktorov, B.Z. and Kozlova, L. A. (2017), Generational-functional analysis of the history of Russian sociology: discussion, Sotsiologiia nauki i tekhnologii, vol. 8, no. 3, pp. 114-129. (In Russian)

25. Kononova, O. and Lyapin, S. (2016), Using the Contextual Search for the Organization Scientific Research Activities, Communications in Computer and Information Science, vol. 674, pp. 392-399, https:// doi.org/10.1007/978-3-319-49700-6_38. 
Authors' information

Ludmila E. Artamoshkina - Dr. Sci. in Philosophy, Associate Professor; le.artspb@gmail.com

Karol Morawski - Dr. Sci. in Philosophy, Senior Lecturer; morawski22@op.pl

Dmitry E.Prokudin — Dr. Sci. in Philosophy, Associate Professor; d.prokudin@spbu.ru

\title{
Цифровая гуманитарная культура и развитие биографического метода
}

\author{
Л.Е. Артамочкина ${ }^{1}$, К. Моравскийํ, Д. Е. Прокудин ${ }^{1}$ \\ ${ }^{1}$ Санкт-Петербургский государственный университет, \\ Российская Федерация, 199034, Санкт-Петербург, Университетская наб., 7-9 \\ ${ }^{2}$ Крконошский государственный университет прикладных наук, \\ Польша, 58-503, Еленя-Гура, ул. Лвовецка, 18
}

Для цитирования: Artamoshkina L. E., Morawski K., Prokudin D. E. Digital humanities and development of the biographical method // Вестник Санкт-Петербургского университета. Философия и конфликтология. 2021. Т. 37. Вып. 2. С. 310-321. https://doi.org/10.21638/spbu17.2021.210

Статья посвящена разработке методологических оснований биографического метода в контексте цифровой гуманитарной культуры. Методологические проблемы разработки биографического метода обусловлены как социальными предпосылками процесса индивидуальной идентификации, так и общим контекстом культуры. Исторически биографический метод связан с тематизацией субъективности, его разработка включает контекст, референцию, достоверность и рефлективность. Авторы статьи подчеркивают значимость биографического метода для исследований памяти в пространстве современного гуманитарного знания, в рамках которого дискуссионными остаются статус истории как науки и ее отношение к человеческой памяти. Обращение к биографическому методу позволяет разработать общий для междисциплинарных исследований памяти (Memory Studies) концептуальный аппарат, позволяющий определить критерии верифицируемости и сопоставимости результатов разнонаправленных научных стратегий. Он включает в себя такие понятия, как тип биографии, биографическое письмо, топология образа, которые служат основанием для разработки процедуры спецификации биографического текста. Авторы подчеркивают обусловленность развития биографического метода состоянием современного информационного общества, создавшего предпосылки для возникновения своего рода «индустрии памяти» (К. Клейн), и намечают перспективы использования инструментов Digital Humanities для его развития. Постоянное возрастание количества текстов в цифровом формате (онлайн-журналов, электронных архивов, биографических директорий электронных библиотек) расширяет эмпирическую базу теоретических исследований, открывая новые возможности для анализа биографических текстов. Авторы демонстрируют возможности применения биографического метода в качестве инструмента цифровой гуманитаристики на примерах исследований по истории науки как значимой части мирового культурного наследия.

Ключевые слова: биография, биографический метод, Ф.Знанецкий, культурная память, цифровая гуманитарная культура.

Статья поступила в редакцию 14 сентября 2020 г.; рекомендована в печать 10 марта 2021 г.

Контактная информация:

Артамошкина Людмила Егоровна - д-р филос. наук, доц.; le.artspb@gmail.com

Моравский Карол - д-р филос. наук, ст. преп.; morawski22@op.pl

Прокудин Дмитрий Евгеньевич - д-р филос. наук, доц.; d.prokudin@spbu.ru

* Статья подготовлена при поддержке гранта РФФИ № 19-011-00775 «Топология культурной памяти в диалоге поколений». 